\title{
真珠腫性中耳炎手術と術後経過の検討
}

\author{
斎藤 武久・久保 富隆・涌井 慎哉・真鍋 恭弘 \\ 坂下 勤武・岩城 詠子・斎藤 等
}

\section{Evaluation of Surgical Therapy and Postoperative Results for Middle Ear Cholesteatoma}

Takehisa Saito, Tomitaka Kubo, Shinya Wakui, Yasuhiro Manabe, Tsutomu Sakashita, Eiko Iwaki and Hitoshi Saito

(Fukui Medical School)

Surgical findings and results in 115 cases of middle ear cholesteatoma were analyzed. In 21 cases of planned staged tympanoplasty, residual cholesteatoma was found in $43 \%$ at the second-stage of surgery. In 94 cases of one-stage tympanoplasty, residual or recurrent cholesteatoma was found in 6\%. Attic retraction pocket which was considered a precurser of recurrent cholesteatoma was found in $23 \%$ during the postoperative course. To avoid a residual cholesteatoma and to maintain the original shape of the external auditory canal, cholesteatoma should be removed by an open-and-closed method in one-stage tympanoplasty. However, staged tympanoplasty is recommended in difficult cases. Furthermore, mastoid obliteration is useful to avoid recurrent cholesteatoma and attic retraction pocket.

In cases that were followed for more than 6 months, hearing improvement (postoperative hearing level within $40 \mathrm{~dB}$ or an Air-Bone gap within $20 \mathrm{~dB}$ or hearing gain over $15 \mathrm{~dB}$ ) was obtained in $91 \%$ for type $\mathbb{I I}$ and $43 \%$ for type $\mathbb{N}$. The incus, malleus, cartilage and plastipore PORP were used as columella materials in type III tympanoplasty and good hearing results were obtained with all of them. In type $\mathrm{N}$ tympanoplasty, good hearing results were obtained by plastipore TORP. The extrusion rate of PORP and TORP was 29\%. It was concluded that more effective means for preventing extrusion of columella are necessary, and that the use of PORP and TORP should be restricted especially in cases with severe middle ear lesions.

Key words: cholesteatoma, recurrence, attic retraction, ossicular reconstraction

はじめに

中耳真珠腫は周囲への進展によって種々の病

像を示し，しばしば手術時に完全郭清が困難な ことや, 術後の再発のために, 未だに治療困難 な耳疾患の一つである. 当科に打ける真珠腫性
中耳炎は1983年10月の開院以来1991年末までに 115耳を数兄，その間に手術法や再発予防のた めの工夫に改善が加えられてきた。 そこでこれ までの手術症例について初回手術時所見や手術 術式，術後成績をまとめ，真珠腫をより確実に 
郭清し再発を予防するためにはどのようにすれ ばよいか，文献的考察を加光て検討を行った。

\section{対 象}

症例は1983年12月から1991年12月までの 8 年 間に真珠腫性中耳炎として当科で手術を行った 115耳である。この間指導的立場にあった術者 は3 名で，それぞれ1983年12月から1985年 4 月 まで，1985年 4 月から1986年 4 月まで，1986年 5 月から現在までを担当した。

\section{結 果}

1. 年齢, 性別分布（図 1 )

年齢は 10 歳以下が 8 耳, 11 20歳が19耳, 21 歳〜30歳が 9 耳, 31〜40歳が26耳, 41〜50歳が 23耳, 51 60歳が11耳, 61〜 70歳が16耳, 71歳 以上が 3 耳で30 40歳代にピークをもち，10歳 以下の小児症例は全体の $7 \%$ を占めるにとどま った。

2. 手術術式と外耳道後壁の処理法

（表 1，2）

耳小骨破壊がなく真珠腫除去後 I 型にできた ものが 4 耳， II 型が 1 耳， III型が 47 耳で，その らち原法は 6 耳, 変法は41耳であった。コルメ ラとして plastipore PORP を24耳，耳小骨（自 家あるいは保存）を 10 耳，耳介軟骨を 7 耳に用 いた。 $\mathrm{N}$ 型は25耳で原法が 3 耳, 変法が 22 耳で あった.コルメラとしては plastipore TORP を 14 耳，耳小骨を 2 耳，耳介軟骨を 6 耳に用い

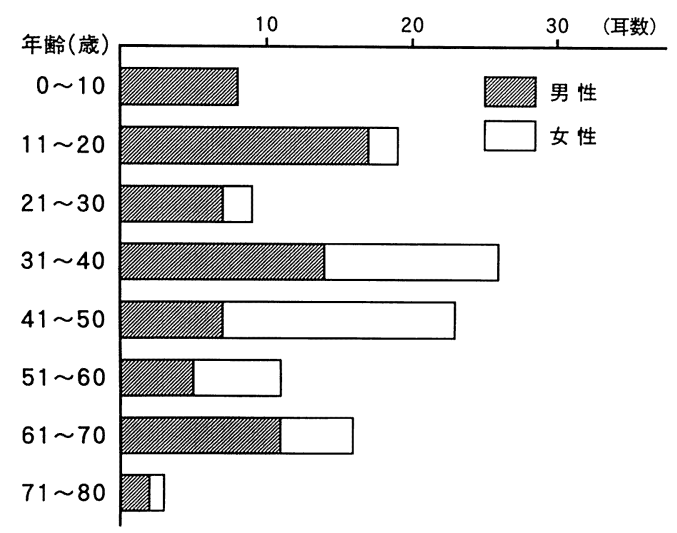

図 1 真珠腫性中耳炎手術例の年龄, 性別分布
た． 0 型は 25 耳に対して行い，すべての症例と も段階手術を目的に行ったが，そのらち21耳に 対して 2 次手術を施行した. 残りの 2 耳はまも なく行ら予定であるが，他の 2 耳は患者の都合 により 2 次手術未施行である.中耳根本術は 13 耳に行ったが，このらち 10 例は最初の 3 年間に 行われたもので，それ以後は特殊な例を除いて 行わない方針で手術に対応している（表 1）。

外耳道の処理法としては, 後壁を保存した closed 法が43耳, 後壁を再建する open and closed 法が54耳, 後壁を再建しない open 法が 5 耳であった。後壁再建に打ける再建材料は側 頭骨皮質骨が38耳，耳介軟骨が16耳であり，こ の中で皮質骨で再建した後，乳突腔を骨片や ハイドロキシアパタイト顆粒で充填したのは 8 耳であった（表 2 ).

表 1 手術術式

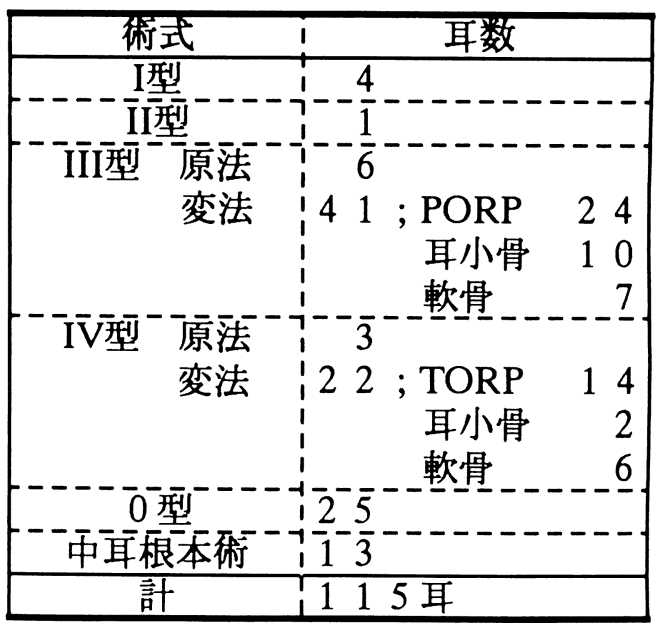

表 2 外耳道後壁の処理法

\begin{tabular}{l|c}
$\begin{array}{l}\text { 後壁保存法 } \\
\text { (closed 法) }\end{array}$ & 43 \\
$\begin{array}{l}\text { 後壁再建法 } \\
\text { (open and closed 法) }\end{array}$ & 54 \\
$\begin{array}{c}\text { open 法 } \\
\text { radical mastoidectomy }\end{array}$ & 13 \\
\hline 計 & 115 耳 \\
\hline
\end{tabular}


3. 初回手術時所見

1 ) 真珠腫進展範囲 (表 3 )

真珠腫の鼓膜の上皮陥入部位あるいは穿孔部 位によって上鼓室型, 後上部型掞よび中鼓室型 に分類した。初回手術87耳の真珠腫進展範囲を 調べてみっと，上鼓室型（49耳）に打いては鼓 室と上鼓室に真珠腫を認めたものが最も多く, 次いで上鼓室のみが多くみられた。後上部型 （24耳）は上鼓室～乳突洞，乳様突起さらに鼓 室内まで広く進展しているものが最も多くみら れた，中鼓室型は当然のことながら鼓室内に多 くみられるが，上鼓室から乳突洞，乳様突起方 向へ進展している症例も認められた。

2 ) 中耳病変の程度

（1）耳小骨破壊（表 4）

真珠腫によると思われる耳小骨破壊の程度は さまざまであるが，上鼓室型と後上部型では 90
\%前後の症例で何らかの耳小骨破壊を認め，そ の半数以上で 2 個以上の耳小骨に破壊を認めた. 一方，中鼓室型ではキヌタ骨長脚〜アブミ骨上 部構造にかけての小範囲の破壊が 6 割を占めて いた。

（2）顔面神経，半規管，脳硬膜の露出（表 5 ） 半規管の露出は $12 \sim 17 \%$ にられ，外側半規 管がほとんどであったが，一部の症例では後半 規管の露出がみられた。半規管に露出があり術 前から聴力が全襲であったのは 12 耳中 2 耳であ り，術後に全襲になった症例はなかった。術後 聴力は段階手術の 2 次手術未施行例の 3 耳を除 いた 9 耳中，改善 5 耳，不変 2 耳，悪化 2 耳で あった。 また段階手術の 2 次手術時に半規管瘦 孔が骨性あるいは結合織によって閉鎖していた 3 耳が確認できた。

真珠腫進展による顔面神経の露出は水平部が

表 3 真珠腫分類と初回手術時の真珠腫進展範囲

\begin{tabular}{c|cccccccc|c}
\hline 分類 & 真珠腫の範囲 & $\mathrm{a}$ & $\mathrm{b}$ & $\mathrm{a}+\mathrm{b}$ & $\mathrm{b}+\mathrm{c}$ & $\mathrm{a}+\mathrm{b}+\mathrm{c}$ & $\mathrm{b}+\mathrm{c}+\mathrm{d}$ & $\mathrm{a}+\mathrm{b}+\mathrm{c}+\mathrm{d}$ & 計 \\
\hline 上鼓室型 & & 12 & 1 & 17 & 10 & 5 & 4 & 49 耳 \\
後上部型 & 4 & 3 & 4 & 1 & 4 & 1 & 7 & 24 耳 \\
中鼓室型 & 4 & 1 & 3 & 1 & 2 & & 2 & 13 耳 \\
正常鼓膜 & & 1 & & & & & & 1 耳 \\
\hline
\end{tabular}

a : tympanic cavity $\quad \mathrm{b}:$ attic $\quad \mathrm{c}$ : antrum $\quad \mathrm{d}:$ mastoid process

表 4 真珠腫分類と初回手術時の耳小骨破壊度

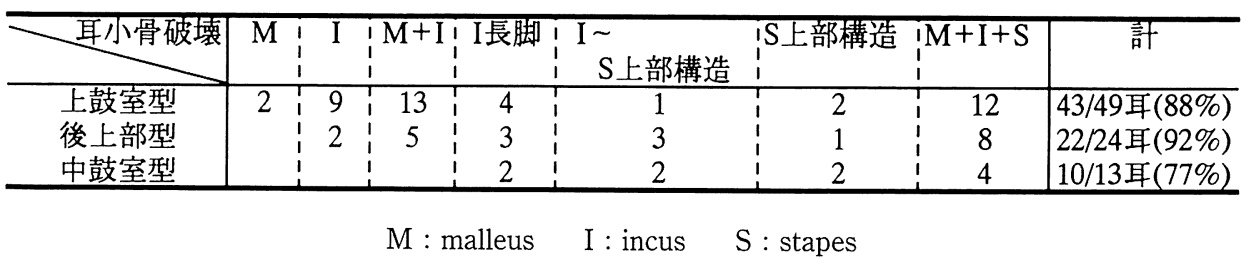

表 5 真珠腫分類と初回手術時の中耳病変

\begin{tabular}{|c|c|c|c|}
\hline & 顔面神経露出 & 半規管毁出 & 脳硬膜毁客出 \\
\hline 上豉室型 & $15 \quad\left(\begin{array}{lll}3 & 1 \%)\end{array}\right)$ & $6(12 \%)$ & $13(27 \%)$ \\
\hline 後上部型 & $(29 \%)$ & ( $17 \%)$ & $\left(\begin{array}{lll}1 & 0 \%\end{array}\right)$ \\
\hline 中鼓室型 & $(31 \%)$ & $(15 \%)$ & ( $31 \%)$ \\
\hline 計 & 26 耳 & 12 耳 & 22 耳 \\
\hline
\end{tabular}


汪とんどで，真珠腫の型に関係なく約30\%の症 例に認められた。このらち術前より麻痺があっ たのは 2 例で，いずれも術後に完全回復した. 術後に麻痺が出現したのは不全麻痺 9 例, 完全 麻痺 1 例であり, 不全麻痺は全例完全回復, 完 全麻痺例は乳突削開時の損傷によるもので回復 はみられなかった。

硬膜の露出はほとんどが中頭蓋窩で一部に後 頭蓋窩で認められ，上鼓室型と中鼓室型で約 30 \%に，後上部型で10\%にみられた.

4. 術後聴力成績 (表 6 )

術後聴力成績の判定は日本臨床耳科学会用語 委員会の “聴力成績の判定と基準案 (1987)” に基づて行った.すなわち術後 6 力月以上の 経過に打いて A-B gap $20 \mathrm{~dB}$ 以内, 聴力レベル $40 \mathrm{~dB}$ 以内, 聴力改善 $15 \mathrm{~dB}$ 以上のいずれかの 条件を満たすものを成功例とした. 伝音再建成 績は 0 型と中耳根本術を除いた77耳に拈いて検 討を行ったが，成績判定の対象となったのは77 耳中 58 耳（75\%）であった． III型は原法で $3 / 3$ $(100 \%)$, 変法でも29/32（91\%）ときわめて 良好な成功率であった。一方， IN 型は原法が 1 耳しか評価の対象にならず（不成功）, 变法で は9/20（45\%）の成功率であった。コルメラ 別の成績を検討すると， III型では PORP, 軟 骨で満足すべき結果が得られた。 N 型では TORP で $62 \%$ の成功率であったが，耳小骨と 軟骨の成績は悪く，この理由としてアブミ骨底 板の動きが悪く術中に聴力改善の期待が少ない と判断された時には, 主に鼓室腔確保のために 術後排出されないコルメラとして耳小骨や軟骨 を用いたことが挙げられる。

\section{5. 段階手術成績（表 7 ）}

段階手術にするかどらかは術者が真珠腫を取 り残す可能性があると判断した場合や，鼓膜緊 張部が広範囲に岬角と癒着し鼓室粘膜の再生を 待つことを目的とした場合に決定される．25耳 に段階手術を予定したが実際に 2 次手術を受け たのは21耳であり，2 次手術までの期間は11〜 13 力月が 11 耳， $7 \sim 10$ カ月 5 耳， 14 18力月 4 耳， 4 カ月 1 耳であった. 2 次手術時に真珠腫 の遺残再発のあった症例は 9 耳 $(43 \%)$ であっ たが，いずれの症例もとの後は再発を認めてい ない，年齢と遺残の関係では20歳以下に率が高 い傾向がみられた。 また残存部位として鼓室内 ではアブミ骨上や鼓室洞，鼓膜裏面に認められ， 上鼓室や乳突洞, 乳突蜂巣に残存している例も あった。

6. 術後経過に括ける問題点（表 8)

1) 真珠腫再発

段階手術症例を除く94耳で再発が認められた

表 7 段階手術例と 2 次手術時の真珠腫遺残例の 年秢分布

\begin{tabular}{c|c|c}
\hline & 段階手術例 & $\begin{array}{c}\text { 2次手術時 } \\
\text { 真珠腫遺残例 }\end{array}$ \\
\hline $0 \sim 10$ & 3 & 2 \\
$11 \sim 20$ & 5 & 3 \\
$21 \sim 30$ & 1 & 0 \\
$31 \sim 40$ & 6 & 2 \\
$41 \sim 50$ & 4 & 2 \\
$51 \sim 60$ & 1 & 0 \\
$61 \sim 70$ & 1 & 0 \\
\hline 計 & 21 & $9(43 \%)$ \\
\hline
\end{tabular}

表 6 鼓室形成術による聴力改善成績

\begin{tabular}{|c|c|c|c|c|c|c|c|}
\hline 術 式 & I 型 & II 型 & III 型原法 & III 型変法 & IV 型原法 & & 型変法 \\
\hline \multirow[t]{2}{*}{ 成功例（率） } & \multirow[t]{2}{*}{$1 / 1$} & \multirow[t]{2}{*}{$0 / 1$} & \multirow[t]{2}{*}{$3 / 3(100 \%)$} & $29 / 32 \quad(91 \%)$ & \multirow[t]{2}{*}{$0 / 1(0 \%)$} & & $9 / 20(45 \%)$ \\
\hline & & & & $\begin{array}{lcc}\text { PORP } & 18 / 19 & (95 \%) \\
\text { 耳小骨 } & 5 / 7 & (71 \%) \\
\text { 軟 骨 } & 6 / 6 & (100 \%)\end{array}$ & & $\begin{array}{l}\text { TORP } \\
\text { 耳小骨 } \\
\text { 軟 骨 }\end{array}$ & $\begin{array}{ll}8 / 13 & (62 \%) \\
0 / 1 & (0 \%) \\
1 / 6 & (17 \%)\end{array}$ \\
\hline
\end{tabular}


のは 6 耳 $(6.4 \%)$ で，遺残性再発は 2 耳，再 発性再発は 4 耳であった。この遺残性再発の 2 耳は再手術を行ったが，再発性再発 4 耳は外来 処置にてコントロール可能であった，再発まで の期間は 1 年 6 力月が 1 耳, 2 年 6 力月が 2 耳, 残りは 4 年 6 力月, 6 年, 7 年 6 力月であった。

2 ）鼓膜穿孔

術後豉膜穿孔を生じたのは 5 耳で，らち 3 耳 に再手術を行った. 残り 2 耳は本人の希望で再 手術を見合わせている。

$3)$ attic retraction pocket

明視できない部位のある上豉室陷凹をきたし たのは19例あったが，いずれの症例も現在まで 真珠腫の再発は認めていない.

4) コルメラの露出, 排出

術後に PORP が排出, あるいは露出後感染 を起こしたために摘出したのが 4 耳，一部が露 出したものの感染のないものが 1 耳あった。 たTORP が排出あるいは摘出したものが 4 耳, 一部露出したものが 2 耳めり，全体では38耳中 11耳（29\%）に露出あるいは排出がみられた。 排出あるいは摘出するまでの期間は 1 年以内 3 耳, $2 \sim 3$ 年末満 2 耳, $3 \sim 4$ 年末满 1 耳, 4 〜 5 年末満 2 耳であり, 長期間経過観察する必 要のあることがわかる.PORP 排出, 露出例 はいずれも一期的手術例であり（5/18耳），2 次手術時に使用した 6 耳は排出はみられなかっ た.一方，TORP 排出，露出例は一期的手術

表 8 術後のトラブル

真珠腫再発, 鼓膜穿孔は段階手術一次手術例を除 く. attic retraction pocket $は$ 段階手術一次手術 例と中耳根本手術例を除く。

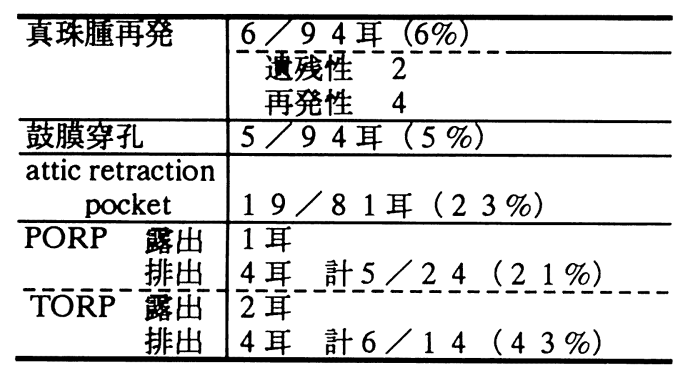

3 耳（3/10 耳)，段階手術耳 3 耳（3/4 耳）で あった。

\section{考 察}

真珠腫性中耳炎の手術で最も問題になるのは 術後再発である. 周知のごとく術後再発には手 術時の遺残による遺残性再発 (residual cholesteatoma) と retraction pocket 内に再発する再発 性再発 (recurrent cholesteatoma) とがある。そ して真珠腫の再発率は術式を問わない場合，5 〜10\%1) 5) が注とんどで，自験例でも $6 \%$ であ った。この再発率は外耳道後壁の処理法によっ て異なるといら成績があり， closed 法よりも open 法の方が再発が少ないといら MarcoAlgarra 56) や鈴木ら ${ }^{4)}$ は，積極的に open 法を 採用すべさであると述べている。これは段階手 術例において一次手術で open 法にした方が 2 次手術時に真珠腫の遺残が少なかったといら大

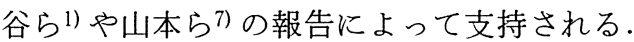

一方, 後壁を保存しても削除しても再発率に差 がなかったとする報告89) もあり，真珠腫の再 発予防においては常に外耳道後壁の処理法打よ び段階手術の是非が問題になってくると思われ る.そこでここでは真珠腫の再発を遺残性と再 発性に分けて, 外耳道後壁の処理法や段階手術 について考察を進めることにする。遺残性再発 を予防するためには，初回手術時にいかに真珠 腫を取り残さないよらにするかが大きなポイン トになることは言らまでもない。その場合，術 後に生理的な外耳道を確保するためには，なる ベく closed 法で行うのが理想である。しかし ながら後壁を削除しなければ処理しにくい真珠 腫があることは誰もが経験するところであり， われわれは真珠腫の完全除去が困難と判断され れば後壁を一旦削除し, 再建を行ら open and closed 法を採用している. 先に述べた後壁処 理法による再発率の報告を再検討してみると， open 法でも closed 法でも再発率に差がなかっ たとする報告者8)9) は，一期的に手術を行い， かつ外耳道保存を心がけるべきであると述べて おり，また open 法の方が再発率が少ないとす 
る報告者の中でも大谷ら ${ }^{1)}$ は, 一次手術で open 法を施行しても 2 次手術では外耳道形成 と乳突腔充塤術を約半数の症例に行っている. では open and closed 法を一期的に行って再発 がなくなるかといえば，決してそらではない。 よほどの熟練者でなければ真珠腫の遺残はある 程度あると考皇なければならない。これに対す る策として，われわれは術中に真珠腫を取り残 す可能性がある場合には段階手術にするように している.もちろん術前に患者に対しては段階 手術になる可能性とその利点について充分に説 明し，理解を得ておく必要があるが，段階手術 は約 1 年後に 2 次手術を行えば遺残真珠腫を容 易に取り除くことができる場合がほとんどであ るといら報告177)10111) は多い，事実，われわれ が行った段階手術では 2 次手術時に 21 耳中 9 耳 （43\%）に遺残を認めたが，その後は一例の再 発も認めていない。この 2 次手術時の真珠腫遺 残率については, 山本ら7)の44\%, 大谷ら”の $13 \%$ ，暁ら ${ }^{2)}$ の38\%といら報告があるが，暁ら は 2 次手術完了後の再発は 1 耳のみで段階手術 の有用性を強調している。しかしながら，初め から段階手術を予定しなくても再発を確認して から手術をすればよいといら意見9)もある。こ れに対して Shelton ら 11 は, 再手術は結局も ら一度手術が必要になることが多く，3 回目の 手術を避けるためにも段階手術は有用であると は反論しており，術中に取り残しがあると感じ た場合，特に再発率の高い小児の場合には段階 手術は取り入れて良い術式であると考える。ま た段階手術は鼓膜の癒着や鼓室内の高度病変を 除去することによって，広範な粘膜欠損をきた す症例には, 鼓室粘膜の再生を待つ意味7) と, 良好な聴力成績を得る11) ために有用であると 思われる。

次に, 再発性再発はそのほとんどが retraction cholesteatoma であったとの報告10) がある ように，術後の鼓膜陥凹には充分な注意を払わ なければならない、 retraction pocket の成因と しては上鼓室の側壁や外耳道の骨欠損が原因で
あるといら比野平ら 12) の報告があるが，それ らの骨欠損を補っても陥凹が生じる例があると し，小川ら13) も closed 法に scutumplasty を行 っても retraction pocket が生じることを認め ている.もら一つの説として retraction pocket は真珠腫の場合に限らず慢性中耳炎でも, 鼓室 〜 上鼓室の炎症が強い場合には，その病巣を充 分に除去したとしても後に中鼓室と上鼓室の間 や中鼓室と乳突腔の間に肉芽, 疲痕組織が増殖 し，この部での狭窄や閉塞をきたすことになる といら本多10)の説がある. われわれの症例で は真珠腫の発生はないものの, 術後に retraction pocket を生じたものが $23 \%$ の高率に認め られ，ある意味で真珠腫再発の予備軍であると いらことができ，長期間にわたる経過観察が必 要である.この retraction pocket を予防する ための策として，乳突腔充填術と前鼓室開放術 が挙げられている．前鼓室開放術は森満14)が 提唱した術式で，上鼓室陥凹を開放して上鼓室 から前鼓室への交通をつける術式であるが，こ れによって真珠腫の再発率は $21.2 \%$ から9.1\% に低下したといら，もら一つの乳突腔充填術は 上鼓室陥凹を予防するのみでなく，一度削除し た後の後壁再建材料を保持して後壁の後退を予 防する意味でも有用であると考兵る。充填材料 としては側頭筋や皮質骨の骨片 ${ }^{13)}$ ， 八イドロキ シアパタイト15)などが挙げられるが，側頭筋 は長期間経過するらちに萎縮し, 後壁が後退し たり retraction pocket を生じたりすることが われわれの経験でもある. また皮質骨は生体の 一部を用いるため，排出されることもなく良い 材料ではあるが，乳突削開に先だって，ある程 度の量を採取しておく必要があること，もし充 填の必要がなくなった場合は採取時間と採取骨 が無駄になってしまうため，最近われわれは八 イドロキシアパタイト顆粒を利用している，症 例によって削開された乳突腔の大きさが異なる が，個々に応じた充填量を自由に変えられる利 点があるからである.今回の検討期間に乳突腔 充填を行ったのは 8 耳であるが，現在も必要に 
応じて行っており，経過は概ね良好である。こ れについては別の機会に報告する予定である.

真珠腫の手術の場合, 再発予防と同時に聴力 改善もあわせて考えなければならないが，真珠 腫の性質上その進展度によって聴力改善の条件 が悪くなっている場合が多い，迷路瘦孔は感音 難聴を引き起こすことがあるが，術中に半規管 露出がみられた症例の中で術前から全壟になっ ていたのは 12 耳中 2 耳で, 術後全䆍になった症 例はなかった． 半規管露出例の術後聴力は, 段 階手術の 2 次手術を未施行の 3 耳を除いた 9 耳 中改善 5 耳, 不変 2 耳, 悪化 2 耳で，充分注意 して真珠腫上皮を除去すれば伝音再建によって 聴力改善が期待でさる15)ことがわかる。また 真珠腫の型によって耳小骨の破壊度に差が生じ るが, Tos ら ${ }^{5)}$ は後上部型の方が上豉室型に比 してアブミ骨上部構造の破壊が強いとし，われ われの症例でも同じような傾向がみられた。こ のようなアブミ骨上部構造の消失している $\mathrm{N}$ 型 になる症例は，聴力改善度も悪い傾向がみられ た。これは正型と $\mathbb{N}$ 型の成績を比較した報 告2)45515)16)すべてに共通している。 また而型, $\mathrm{N}$ 型とも原法に比べてコルメラを用いた变法の 方が成績が良いといら点でも一致している。 ルメラとしては人工材料の方が術後聴力が良い とされ717)，われわれも plastipore PORT， TORP を用いて術後聴力の成功率が $95 \%, 62$ \%と満足すべき結果を得た。しかしその反面， 自家骨や軟骨は全く排出されないのに対して人 工材料は排出される例が必ずあるといら問題点 がある. plastipore は周囲に生体内变性 (biodegeneration) が起こるために異物反応を生じ, 排出につながるといわれている18)。われわれは 鼓膜とコルメラの間に耳介軟骨片を置いている が，それでも排出と露出を含めて $29 \%$ といら成 績であり，これは大谷ら1)の $26.7 \%$ とほぼ同率 であった。一方，セラミック製コルメラは plastipore よりも排出率が低(17) とされるが, 中村らは $20 \%$ の排出がある19) とし, 山本ら ${ }^{20)}$ は軟骨板の使用により $7 \%$ といら成績を挙げて
いる.これらの排出率を低いと考えるか，あく まで排出されること自体に問題があると考える か，これは今後さらに検討が必要と思われるが， われわれは病変の高度な症例に一期的手術をす ると術後耳管機能不全による含気腔の形成不全 が生じ, 鼓膜の陥凹, そして人工ュルメラの排 出につながるという報告21)を支持しており， 中耳奇形など炎症所見のほとんどない場合の使 用は良いが，中耳病変が高度な場合にはまず段 階手術によって鼓室内の状態を改善してから人 エコルィラを用いるか，もしくは人工物の使用 は避けた方が良いのではないかと考えている。

\section{まとめ}

開院以来 8 年間に行われた 115 耳の真珠腫性 中耳炎手術について, 術中所見亡術後経過をも とにして，真珠腫再発を予防するための外耳道 後壁処理法や段階手術の意義, さらに聴力改善 のためのコルメラの使用について検討を行った.

1.段階手術を行った 21 耳中 9 耳 $(43 \%)$ で 2 次手術時に真珠腫の遺残を認め, 一期的手術 94耳中 2 耳に遺残性再発，4耳に再発性再発を 認めた（計 6 耳， $6 \%$ ）。段階手術耳は 2 次手 術以後, 再発は 1 例もなかった.

2 . 術後経過中に attic retraction pocket 生じたものは，段階手術一次手術例と中耳根本 術を除く81耳中19耳 (23\%) であった。

3 . 術式は正型と $\mathbb{N}$ 型が $94 \%$ を占め， II 型原 法 3/3（100\%)，变法 29/32（91\%)， $\mathbb{N}$ 型原法 0/1（０\%），変法 9/20（45\%）の聴力成績成 功率であった。 III型変法のコルメラは, PORP (95\%)，耳小骨 $(71 \%) ，$ 軟骨 $(100 \%)$ と，と もに成功率は高かったが， IV型では TORP の $62 \%$ み成功率が高く，耳小骨，軟骨の成績は 不良であった。

4. コルメラのらち耳小骨, 軟骨は排出例が なかったが, plastipore PORP は排出 4 耳, 露 出 1 耳, TORP は排出 4 耳, 露出 2 耳で計 $11 /$ 38 （29\%）であった.

5. 遺残性真珠腫を予防し外耳道の形態を保 つためには, 後壁処理法としての open and 
closed 法と段階手術を積極的に取り入れるこ とが有効であり，再発性再発の予防にはさらに 乳突腔充填術の併用が有効であると考察した。

6 . 聴力改善を目的として使用される人工コ ルメラは排出される可能性があり, 今後さらに 排出予防の工夫をする必要性と, 中耳内病変の 高度な症例には慎重に使用すべきであるという 点を強調した。

\section{参考文献}

1）大谷 㹈, 大梘好正, 相川 通, 他: 中耳真珠 腫に対する段階的鼓室形成術 一一期的鼓室形 成術との比較検討一. 耳鼻臨床 補 $10 ： 96 \sim 106$, 1987.

2）暁 清文, 佐藤英光, 浅井真紀, 他: 当科に打 ける真珠腫症治療の現況.耳鼻臨床 $80: 1369$ 〜 1375, 1987.

3) Sanna M, Zini C, Camoletti R, et al : Prevention of recurrent cholesteatoma in closed tympanoplasty. Ann Otol Rhinol Laryngol 96 : 273 275, 1987.

4）鈴木 勲, 星 慎一, 柏戸 泉, 他：当科に拧 ける慢性中耳炎の手術成績 一正型变法, $\mathbb{N}$ 型 変法を中心として一. 耳鼻 $37: 1083 \sim 1089$, 1991.

5) Tos $M$ and Lau $T$ : Late results of surgery in different cholesteatoma types. ORL $51: 33 \sim$ 49, 1989.

6) Marco-Algarra J, Gimenez F, Mallea I, et al : Cholesteatoma in children ; results in open versus closed techniques. J Laryngol Otol 105 : $820 \sim 824,1991$.

7）山本悦生, 山内盛雄, 岩永迪孝: 段階的鼓室形 成術 -100 耳の経験から一. 耳鼻臨床 76 增 1 : 414 423, 1983.

8) Tos $M$ and Lau T : Attic cholesteatoma; recurrence rate related to observation time. Am J Otol 9 : 456 464, 1988.

9）宮永 敏, 森満 保, 松元一郎, 他: 小児真珠
腫性中耳炎手術成績. 耳鼻 $33: 422 \sim 426,1987$.

10）本多芳男：中耳真珠腫の成因論. 耳喉 $59: 791$ $\sim 800,1987$.

11) Shelton $C$ and Sheehy JL: Tympanoplasty; review of 400 staged cases. Laryngoscope $100: 679 \sim 681,1990$.

12）比野平恭之, 暁 清文, 柳原尚明, 他: 真珠腫 症に拈ける術後性ポケットの成因. 耳鼻臨床 83 : 1793 1798, 1990.

13）小川 裕, 田村嘉之, 宮永 守, 他: 小児真珠 腫の術後長期成績. 臨床耳科 $15: 35 \sim 40,1988$.

14）森満 保：中耳真珠腫の発症 一特に前鼓室の 意義一. 耳鼻 37 補 $1: 271 \sim 405,1991$.

15）高橋 姿：ハイドロキシアパタイト顆粒塊を用 いた乳突充填鼓室形成術 一臨床的ならびに実 験的研究一. 日耳鼻 $94: 833 \sim 842,1991$.

16）八木聡明 : 鼓室形成術1006耳の検討. 耳喉頭頸 $64: 117 \sim 121,1992$.

17) Gersdorff $M$ and Andre $M: A$ comparative study of the clinical results obtained with plastipore and ceramic ossicular prosthesis in otologic surgery. Arch Otorhinolaryngol $243: 20 \sim 23,1986$.

18) Frootko NJ : Failed ossiculoplasty using porous polyethylene (Plastipore ${ }^{\mathbb{R}}$ ) prosthesis. J Laryngol Otol $98:$ 121 126, 1986.

19）中村一, 森弘, 岩永迪孝, 他: セラミッ ク耳小骨の露出, 排出例について。臨床耳科 $13: 282 \sim 283,1986$.

20）山本悦生，広野喜信，奥村智子：セラミック耳 小骨 (CORP) 使用例の長期観察結果. 日耳鼻 $90: 1262 \sim 1266,1987$.

21) Yamamoto $E$ and Iwanaga $M$ : Ossiculoplasty failure with ceramic replacement prosthesis. ORL 48 : 332 337, 1986.

別刷請求先 : 斎藤武久 910-11 福井県吉田郡松岡町下合月 23-3
福井医科大学耳鼻咽喉科学教室 